\title{
Special Editorial: WAC in the Time
} WAE of Coronavirus

\author{
John Carman, Ironbridge International Institute for Cultural Heritage, University of \\ Birmingham, Birmingham, UK \\ E-mail: J.Carman@bham.ac.uk
}

Jan Turek, Center for Theoretical Study, Charles University, Prague, Czech Republic

We do not usually write an Editorial for a Special Issue. This, however, is a 'special editorial' written in an emergency situation. As we are in global war with the invisible enemy of Covid-19 Coronavirus pandemic, we face many restrictions and safety measures worldwide. For WAC, the most painful consequence is the postponement of WAC-9 (see the announcement by the WAC President) that was supposed to be held in Prague, 5-10 July 2020.

WAC as a global organization is responsible for the safety of its membership during the main congresses and inter-congresses. At the time of writing this Editorial, the situation is not getting any better, just the opposite. While in China and South Korea we can see the first signs of successful quarantine, the pandemic reached Iran, Europe and North America in February, and decisively affected the lives of millions of people. The pandemic is still rising, and one of the Archaeologies co-editors is currently in quarantine.

Concerning the prospect of WAC-9, we decided to postpone it by a whole year, so the current dates of the Prague congress are 4-9 July 2021. This wasn't an easy solution but definitely the most safe and responsible one. Nobody knows how the pandemic is going to behave in the rest of this year; however, some epidemiologists are warning that there may be an autumn recurrence of the virus. So we hope that July 2021 may be the time in which we either have the virus globally under control and/or have the vaccine and medication available. Then we could organize the meeting without stress and fear and make our global meeting even more successful.

The reason why we are so surprised and unprepared for the global disease outbreak is that the immediate experience with such danger has disappeared from our living memory. The 1918 influenza pandemic called the 'Spanish flu' occurred at the end of WW I, more than hundred years ago.

The occurrence of global pandemics has a very long pedigree. Some of the Copper Age (Bateni in Russia-Afanasievo Culture 2909-2679 BC; Scope in Estonia-Corded Ware Culture 2575-2349 BC; Bulanovo in Russia-Sintasha Culture 2280-2047 BC) and Early Bronze Age burials from Central and Eastern Europe (Chociwel in Silesia-Poland-Únětice Culture 2135-1923 BC; Kytmanovo in Russia-Andronovo Culture 1746-1626 BC) 
contained DNA from bacterium Yersinia pestis that caused the Black Death (Callaway 2015). This spread is usually connected with the migration of the Yamnaya Culture population westwards. These earliest cases of plague lacked a gene called ymt that helps the bacterium Yersinia pestis to colonize guts of fleas (often travelling on rodents) transmitting bacteria to humans. The later example comes from Early Iron Age Armenia 1048-855 BC, from the cemetery at Kapan, where the bacterium Yersinia pestis already harbouring the $y \mathrm{tm}$ was identified together with another mutation linked to fleaaided transmission. Since then, the plague became a fast spreading disease of civilization, such as in the case of the Medieval Bubonic plague (Callaway 2015). The earliest historical evidence of plague comes from 5th century $\mathrm{BC}$ Athens, the city-state that was at the time engaged in the Peloponnese War. So the mobility of humans and rodents and social misbalance, such as wartime, were the worst accelerators of pandemics.

Medieval globalization brings the first recorded truly global outbreak of plague that first occurred in China in the 1330s, a time when China was engaged in substantial trade with Western Asia and Europe. The plague reached Europe in October 1347.

The diseases commonly 'travelled' from East to West. In 1529, a measles outbreak in Cuba killed two-thirds of the natives who had previously survived European smallpox. Two years later, measles was responsible for the deaths of half the indigenous population of Honduras, and ravaged Mexico, Central America and the Inca civilization.

In the modern world, the flow of ideas, information, goods, capital, and people across political and geographic boundaries allow infectious diseases to rapidly spread around the whole planet. The third plague pandemic emerged in Yunnan province of China in the mid-19th century. It spread east and south through China, reaching Guangzhou (Canton) and the British colonial port of Hong Kong in 1894, where it entered the global maritime trade routes. Plague reached Singapore and Bombay in 1896.

Most similar to our current struggle is the outbreak of Spanish flu (1918-1920) that infected 500 million people around the world, or about $27 \%$ of the world population which was at that time between 1.8 and 1.9 billion. The death toll was estimated to have been anywhere from 17 million to 50 million or perhaps even more. The disease originated probably in Northern China and spread with the movement of soldiers and trade globally. In Europe and North America, it badly affected countries involved in the World War. Unlike Covid-19, it mainly killed young people in reproductive age. It came in three waves (see Fig. 1). The first wave started in late 1917 and early 1918. The second wave of the 1918 pandemic was much deadlier than the first. The first wave had resembled typical flu epidemics; those most at risk were the sick and elderly, while younger, healthier people recovered easily. By August, when the second wave began in 


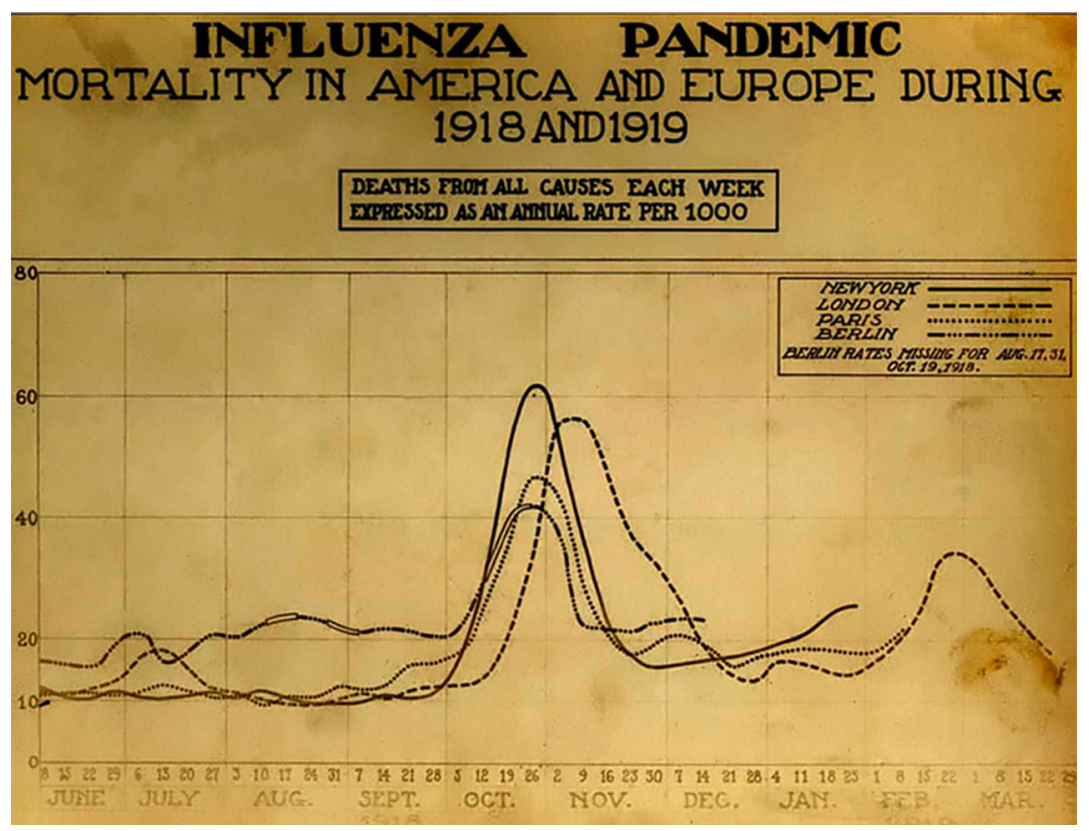

Figure 1. Influenza Pandemic Mortality in America and Europe During 1918 and 1919

France, Sierra Leone, and the USA the virus had mutated to a much deadlier form. October 1918 was the deadliest month of the whole pandemic. The third wave came in February/March 1919 (Fig. 1).

Much has changed in medical science and technology since the time of Spanish flu, but with ever-growing population and the unprecedented mobility of present day humankind we face new and yet unknown challenges of the 21st Century Global pandemic.

We wish us all good health, open mind and good luck in coming time.

See you in Prague 2021!

Fig. 1 source:

Image: courtesy of the National Museum of Health and Medicine)-Pandemic Influenza: The Inside Story. Nicholls H, PLoS Biology Vol. 4/2/2006, e50 https://dx.doi.org/10.1371/journal.pbio.0040050, Public Domain, https:// commons.wikimedia.org/w/index.php?curid=1441889

\section{Reference}

Callaway, E.

(2015). Bronze Age skeletons were earliest plague victims, Nature. https://doi. org/10.1038/nature2015.18633. 
WAC-9-List of Sessions

The following list of currently opened WAC-9 sessions may be inspiration for you to attend the 2021 WAC-9, present your research and enjoy our ever-growing global archaeological family!

\section{A. Archaeological Practices}

\section{Global Perspectives on Rock Art}

1. The artists behind the art: Rock art created by known artists

Joakim Goldhahn (Linnæus University, Sweden), Sally Kate May (Griffith University, Australia)

2. Multidimensional Materials: Rock Art, Relationality, and Change Through Time and Space

Rebecca O'Sullivan (Jilin University, China), Courtney Nimura (University of Oxford, United Kingdom), Liam Brady (Monash University, Australia), Jamie Hampson (University of Exeter, United Kingdom)

3. Semiotic inferences from clusters of non-figurative marks from Palaeolithic rock art to pottery and ceramics in the Iron Age

Paul Bouissac (University of Toronto, Canada), Dragos Gheorghiu (National University of Arts, Bucharest, Romania), Martin Uildricks (Brown University (Institute for Archaeology), Providence RI, United States)

4. Anthropological and Archaeological Perspectives on Hand Imprints in Rock Art

Suramya Bansal (Rock Art Research Institute, University of the Witwatersrand, South Africa), Brea McCauley (Department of Archaeology, Simon Fraser University, Canada)

\section{World Views of Contact}

Sam Challis (Rock Art Research Institute, University of the Witwatersrand, South Africa), Jamie Hampson (University of Exeter, United Kingdom)

6. Revisiting regionality to understand world rock art

Ndukuyakhe Ndlovu (University of Pretoria, South Africa), Inés Domingo-Sanz (University of Barcelona, Spain)

7. From within: current approaches to the study of human/otherthan-humans in (rock) art studies

Ana Paula Motta (Centre for Rock Art Research and Management, University of Western Australia, Argentina), Jo McDonald (Centre for Rock Art Research and Management, University of Western Australia, Australia), Sven Ouzman (Centre for Rock Art Research and Management, University of Western Australia, South Africa), Martin Porr (Centre for Rock Art Research and Management, University of Western Australia, Germany) 
2. Why Archaeology Needs Ethnoarchaeology

1. Archaeology and Caravans in Comparative Prospective

Mario A. Rivera (ICOMOS Chile, Chile), Olga Gabelmann (University of Bonn, Germany)

2. Breaking Bread and Raising a Glass: Bridging Ethnoarchaeological and Archaeological Research on Food and Culinary Habits

John Arthur (University of South Florida, United States), Soultana Maria Valamoti (Aristotle University of Thessaloniki, Greece)

3. Global Perspectives on the Archaeology and Ethnoarchaeology of Salt

Paul Eubanks (Middle Tennessee State University, United States), Marius Alexianu (Universitatea Alexandru Ioan Cuza Iasi, Romania)

4. Ethnoarchaeology and Later European Prehistory-Venturing the Ridge between Hypothesis, Plausibility, and Evidence

Holger Wendling (Salzburg Museum/Keltenmuseum Hallein, Austria), Ulrich Veit (University of Leipzig, Germany)

5. Ethnoarchaeology: From Research Tool to Foundational Archaeological Epistemology

Alok Kumar Kanungo (IIT Gandhinagar, India), Sharada V. Channarayapatna (IIT Gandhinagar, India), Adam S. Green (University of Cambridge, United Kingdom), Jordan Ralph (Flinders University, Australia)

\section{Contemporary Archaeologies}

1. Archaeology, resistance and engagement: the archaeology(ies) of contemporary past under dictatorship

Leila Papoli-yazdi (Gothenburg University, Sweden), Maryam Dezhamkhooy (Frankfurt University, Germany), Omran Garazhian (University of Neyshabour, Iran)

2. Entangled heritage in the making of Anthropocene: critical perspectives on materiality, iden-tity and fluidity of heritage

Tiago Muniz (Linnaeus University, Sweden), Monika Stobiecka (University of Warsaw, Poland)

3. The Archaeology of Zoos-Reloaded

Cornelius Holtorf (Linnaeus University, Sweden), Kola Adekola (University of Ibadan, Nigeria)

4. Archaeologies of modern/colonials projects in Latin America

Wilhelm Londoño (Universidad del Magdalena, Colombia), Luis Gerardo Franco (Investigador independiente, Colombia), Dante Angelo (Universidad de Tarapaca, Chile)

5. Contemporary Approaches to the Study of Cultural Erasure 
Brian Daniels (University of Pennsylvania, United States), Zoya Masoud (Technische Universität Berlin, Germany)

6. Archaeologies of Contemporary (Political) Global Settings/Arqueologías de contextos políticos contemporáneos globales/Arqueologias de Cenários Globais Contemporâneos (Políticos)

Dante Angelo (Universidad de Tarapacá, Chile), Andrés Zarankin (Universidad Federal de Minas Gerais, Brazil), Nestor Rojas (Universidad de Tarapacá, Chile), Jordan Ralph (Flinders University, Adelaide, Australia)

\section{High-Spirited Gatherings or Lightning Sessions}

1. Lightning Strike Wakes Archaeologists and they Challenge Colonial-Indigenous Master Narratives!

Kathryn Weedman Arthur (University of South Florida, United States), Liam Frink (University of Nevada, Las Vegas, United States), Natalie Swanepoel (University of South Africa, South Africa), Kristen Barnett (Bates College, United States)

2. The Archaeology of Coincidence?

Larry Zimmerman (Indiana University-Purdue University Indianapolis, United States), Stephen Loring (Smithsonian Institution, United States), Gary Jackson (Flinders University, Australia)

\section{B. Archaeological Praxis}

\section{Evaluating Archaeological Knowledge}

1. The "Ontological Turn"-Theory and Praxis

Talia Shay (Technion Institute of Technology (former), Israel), Marie Pyrgaki (Université Paris I, Panthéon-Sorbonne Cons. Prof. Hellenic Open University, Greece), Lilen Malugani Guillet (Universidad Nacional de Catamarca, Argentina)

2. Applying knowledge of symbolism and other subtle indications relevant to cultural values that can aid the interpretation of prehistoric monuments

Terence Meaden (Oxford University, United Kingdom), Thomas Wyrwoll (German Society for Rock Art Research, Germany)

3. Indigenous Peoples and New Techniques for Provenance Research: Opportunities, Challenges and Risks

Paul Turnbull (National Centre for Indigenous Studies, Australian National University; University of Tasmania, Australia), Edward Halealoha Ayau (Former Executive Director, Hui Mālama I Nā Kūpuna O Hawai'i 
Nei, United States), Lyndon Ormond-Parker (Indigenous Studies Unit, Centre for Health Equity, University of Melbourne, Australia)

4. With a little help from our friends: Digital archaeological knowledge production through engagement with non-professionals (Round Table)

Suzie Thomas (University of Helsinki, Finland), Stijn Heeren (Vrije Universiteit Amsterdam, Netherlands)

5. 'What have the Romans ever done for us?' The Roman Past and 21st Century Politics

Emily Hanscam (Durham University, United Kingdom), Matthew Mandich (ISAR, Italy), Russell Ó Ríagáin (Universität Heidelberg, Germany), Tatjana Cvetičanin (National Museum in Belgrade, Serbia)

\section{Discrimination and Injustices}

1. Thirty years on: has the Vermillion Accord steered change?

Wendy Black (Iziko Museums of South Africa, South Africa), Morongwa Mosothwane (University of Botswana, Botswana)

2. Instruments of Ownership in Archaeology and Digital Heritage

Neha Gupta (The University of British Columbia, Okanagan, Canada), Kate Ellenberger (Heritech Consulting, United States), Ramona Nicholas (University of New Brunswick, Canada), Sue Blair (University of New Brunswick, Canada)

3. Archaeology and the Future of Democracy-the 2019 EAA Bern Statement in a global context (Round Table)

Thomas Meier (University of Heidelberg, Germany), Sophie Hueglin (European Association of Archaeologists, United Kingdom)

4. Decolonization of Classics and Classical Archaeology

Louise Hitchcock (The University of Melbourne, Australia), Christopher Hale (O.P. Jindal Global University, India)

5. Discrimination and Injustices in Archaeological Daily Practices: sharing experiences, seeking solutions (Round Table)

Koji Mizoguchi (President of the World Archaeological Congress, Kyushu University, Japan)

C. Heritage

7. Community Approaches to Archaeology and Heritage Management

1. African Archaeologists, African Heritage Managers

Emmanuel Ndiema (National Museums of Kenya, Kenya), Kenneth Aitchison (Heritage Management Organization, United Kingdom) 
2. Straight talk: What does and what does not constitute community archaeology? (Round Table)

Peter Schmidt (University of Florida and University of Pretoria, United States), Jagath Weersinghe (PGIAR, University of Kelaniya, Sri Lanka)

3. Heritage as An Action Word: Uses Beyond Communal Memory

Kelly Britt (Brooklyn College, CUNY, United States), Susan Shay (Cambridge University, United Kingdom)

4. How Should We Carry Out a Public Archaeology Project? Towards a Methodology for Public Archaeology in the context of Development

Daniel Dante Saucedo Segami (Ritsumeikan University, Japan), Agathe Dupeyron (University of East Anglia, United Kingdom)

5. From community engagement to engaged community: lessons from public archaeology for sustainable heritage

József Laszlovszky (Central European University, Hungary), Petar Parvanov (Central European University, Bulgaria)

6. Recipes for community-engaged art and archaeology (Round Table)

Yasuyuki Yoshida (Center for Cultural Resource Studies, Kanazawa University, Japan), Ilona Bausch (Sainsbury Institute for the Study of Japanese Arts and Cultures, Netherlands)

7. Values, Heritage, and the 'Package'

Prerana Srimaal (Christ (Deemed to be University), Bangalore, India), Gillian Juleff (University of Exeter, United Kingdom), Anura Manatunga (University of Kelaniya, Colombo, Sri Lanka)

8. Migrating people, migrating identities: Archaeological heritage and its potential in solving migration crises

Laura Coltofean-Arizancu (University of Barcelona, Spain), Camila Opazo (University of Barcelona, Spain), Isber Sabrine (Institució Milà i Fontanals CSIC and Heritage for Peace, Spain), Marcela Jaramillo (Instituto Universitário de Lisboa (ISCTE-IUL), CRIA, Portugal)

9. Contemporary Archaeology and Heritage Studies; Delving into Dark Heritage

Kiara Beaulieu (University of Birmingham, Canada), Benedetta Rossi (University of Birmingham, United Kingdom), Djiguatte Amédé Bassene (École des Hautes Études en Sciences Sociales de Paris, Senegal), Patrick Abungu (Shimoni Slavery Museum \& Heritage Site, Kenya)

8. Transdisciplinary and Unbounded: Contemporary Approaches to Critical Heritage Studies

1. Qurnawis and Egyptologists: An ontologically equivocated relationship 
José Roberto Pellini (Universidade Federal de Minas Gerais_-Brazilian Archaeological Program in Egypt, Brazil), Bernarda Marconetto (IdacorConicet. Cordoba National University, Argentina)

2. Changing heritage policy and practice in the Middle East in an age of neoliberalism

Robin Skeates (Durham University, United Kingdom), Shatha AbuKhafajah (Hashemite University, Jordan)

3. Phantom Limb: Contextualizing Critical Heritage work in between the intersections of Contemporary Art and Archaeology

Uzma Z. Rizvi (Pratt Institute, United States), Nora Razian (Art Jameel, United Arab Emirates)

4. International Perspectives on Heritage and Public History Education (Round Table)

Alicia McGill (North Carolina State University, Department of History, United States), Jaroslav Ira (Charles University, Department of History, Czech Republic), Tammy Gordon (North Carolina State University, Department of History, United States)

5. Archaeogaming and decolonising narratives: retelling the stories of the marginalise

Bruno S. R. da Silva (Federal University of Sergipe, Brazil), Priscilla Ulguim (Teesside University, United Kingdom)

6. Early Watercraft: The oldest dispersed global humankind cultural heritage

Miran Erič (Institute for the Protection of Cultural Heritage of Slovenia, Slovenia), David Payne (Australian National Maritime Museum, Australia)

7. The Things They Carry: Human Bodies and the Burden of Meaning

Annalisa Bolin (Linnaeus University, Sweden), Meredith Reifschneider (San Francisco State University, United States)

8. Archaeology and the management of sensitive cultural heritage: trends and directions

Alejandra Saladino (Universidade Federal do Estado do Rio de Janeiro (UNIRIO), Brazil), Camila Moraes Wichers (Universidade Federal de Goiás, Brazil), Leandro Matthews Cascon (Universiteit Leiden, Netherlands), Manuelina Duarte Cândido (Université de Liège, Belgium)

9. Exploring histories of collecting human remains: local and international contexts, networks and repatriation processes

Carl-Gösta Ojala (Uppsala University, Sweden), Hirofumi Kato (Hokkaido University, Japan), Eeva-Kristiina Harlin (University of Oulu, Finland)

10. The integration of socially relevant policy topics into Heritage Management Education (HME) (Round Table) 
Annemarie Willems (Helsinki University, Netherlands), Suzie Thomas (Helsinki University, Finland), Kenneth Aitchison (Heritage Management Organization, United Kingdom)

11. Archaeology of non-commemoration: memorialization practices of war

Ana Bezić (University of Rijeka, Croatia), Milica Tomic (Technical University Graz, Austria)

9. Trade in Art, Culture, and History: Heritage Tourism in the TwentyFirst Century

1. Community Archaeology and Management of heritage Sites and Museums

Chapurukha Kusimba (American University, United States), Pastory Bushozi (University of Dar es Salaam, Tanzania)

2. Heritage Tourism: A boon or threat for Management \& Sustainability of Heritage sites

Asmita Basu (Army Institute of Management, India), Sergiu Musteata ("Ion Creanga" State University, Moldova), Prabir Biswas (Harimohan Ghose College, India), Edoardo Bedin (National Trust for Scotland, United Kingdom)

3. Archaeology as an Engine for Sustainability in the Countries of the Maya World

Lilia Lizama (Fulton County Schools, ICAHM-Manejo Cultural,AC., United States), Ivan Batún (Universidad de Oriente, Mexico), Israel Herrera (Universidad de Campeche, Mexico), Kennedy Obombo (Instituto Tecnológico de Cancún, Mexico)

4. Responding to Overtourism at Heritage Sites

Valerie Higgins (American University of Rome, Italy), Athena Hadji (Hellenic Open University, Greece), Anna Sasso (American University of Rome, Italy)

\section{Indigenous}

10. Indigenous Views on Ancestors, Ancestral Sites, their Excavation and Disturbance

1. Indigenous Insights that Improve Policy and Practice in Cultural Heritage Management (Round Table)

Dorothy Lippert (Smithsonian National Museum of Natural History, United States), Des Kahotea (Waikato University, New Zealand), Desiree Martinez (Cogstone Resource Management Inc., United States) 
2. Engaging Indigenous communities, ancestral remains, sites and archaeological practice in the Islands of Hawaii and South Asia

Aulii Mitchell (Cultural Surveys, Hawai'i), Tiatoshi Jamir (Nagaland University, India)

\section{Archaeology as indigenous Advocacy}

1. Recent Issues and Future Possibilities of Public Archaeology and Anthropology on Indigenous People in East Asia

Hideyuki Ōnishi (Doshisha Women's College of Liberal Arts, Japan), Maa-ling Chen (National Taiwan University, Taiwan)

2. Indigenous archaeologies and histories from the South America

Juliana Salles Machado (Federal University of Santa Catarina, Brazil), Michael Heckenberger (University of Florida, United States)

3. Global perspectives on decolonising rock art knowledge

Leslie F. Zubieta Calvert (Universitat de Barcelona, Spain), Raoni Valle (Universidade Federal do Oeste do Pará, Brazil)

4. Realizing Ucko's Dream: Winning Maya Indigenous Land Right$s$ (Round Table)

Anne Pyburn (Indiana University Bloomington, United States), Cristina Coc (Julian Cho Society, Belize), Pablo Mis (Maya Leaders Alliance, Belize), Filiberto Penados (CELLA Belize, Belize)

\section{Fission or Fusion? Indigenous Engagement}

1. Profit and Loss: Commercial Trade in Ancestral Remains

Gareth Knapman (Australian National University, Australia), Timothy McKeown (Independent Scholar, United States), Amber Aranui (tepapa museum, New Zealand), Cressida Fforde (Australian National University, Australia)

2. Heritage and Reconciliation

Cressida Fforde (The Australian National University, Australia), Peter Stone (University of Newcastle, United Kingdom), Paul Tapsell (University of Melbourne, Australia)

3. Archaeology's Place in Reclaiming and Reconciliation: Indigenous Paths to Healing

Paulette Steeves (Algoma University, Canada), Pirjo Kristiina Virtanan (University of Helsinki, Finland), Ranjan Datta (University of Saskatchewan, Canada)

4. Sites of indigenous wellbeing

Paul Tapsell (University of Melbourne, Australia), Jamie Metzger (University of Otago, New Zealand) 
5. Repatriation, Restitution, and Reburial from a South American Perspective

Patricia Ayala (Sociedad Chilena de Arqueologia, Bolivia), Jacinta Arthur (Programa de Repatriación Rapa Nui, Chile), Mariela Eva Rodríguez (Universidad de Buenos Aires, Argentina)

6. Looking Back, Looking Forward: $\mathbf{4 0}$ years of repatriation

Paul Tapsell (New Zealand Maori Centre of Research Excellence, University of Otago, New Zealand, New Zealand), Hilary Howes (The Australian National University, Australia), Robert Kelly (Flinders University, Australia), Gareth Knapman (The Australian National University, Australia), Amber Aranui (Museum of New Zealand Te Papa Tongarewa, New Zealand), C. Timothy McKeown (Central European University, Austria)

7. Envisioning Indigenous Archaeological Futures: Creating Sustainable Paths Forward for Future Generations (Round Table)

Ora Marek-Martinez (Northern Arizona University, United States), Sara Gonzalez (University of Washington, United States), Kisha Supernant (University of Alberta, Canada)

E. Interactions and Transformations

\section{Historical Archaeology: Global Alterities and Affinities}

1. To be buried as a warrior: Burials, social and military structures on the edge of the Frankish Empire (8th-10th centuries)

Ivo Štefan (Department of Archaeology, Charles University Prague, Czech Republic), Howard Williams (University of Chester, United Kingdom)

2. Where to from here? Decolonising historical archaeology in practice and theory

Natalie Swanepoel (University of South Africa, South Africa), Dores Cruz (University of Cologne, Germany)

3. The Expansion of the Mongol Empire in the Thirteenth Century: Archaeological, Climatic and Historical Interpretations

József Laszlovszky (Central European University, Hungary), Nikolay Makarov (Institute of Archaeology, Russian Academy of Sciences, Russian Federation)

4. The Ottoman Empire on the Frontiers of Europe: Approaches in the Framework of Early Modern and Historical Archaeology

Gábor Tomka (Hungarian National Museum, Hungary), Günhan Börekçi (Central European University, Medieval Studies Department, Turkey) 


\section{Maritime Histories: The Seas in Human History}

\section{Aquatic Neolithic Formations in Global Perspective}

Mark Hudson (Max Planck Institute for the Science of Human History, Germany), Junzo Uchiyama (Sainsbury Institute for the Study of Japanese Arts and Cultures, United Kingdom)

2. Global Evidence of the Late Pleistocene Seafaring and Maritime Adaptation: When, Where, and How

Rintaro Ono (National Museum of Ethnology, Japan, Japan), Sue O’Connor (The Australian National University, Australia), Yousuke Kaifu (National Museum of Nature and Science, Tokyo, Japan), Jon Erlandson (University of Oregon, United States)

3. Peninsular Maritime Trade and Interaction during Prehistoric and Historic Periods in East Asia

Lauren Glover (The University of Wisconsin-Madison, United States), Jina Heo (Seoul National University, Korea)

4. Cultural interactions across the Bay of Bengal and beyond

Kaushik Gangopadhyay (Department of Archaeology, University of Calcutta, India), Coline Lefranq (CNRS-CEIAS-UMR 8564, Belgium), Selvakumar Veeraswamy (Department of Maritime History and Marine Archaeology Tamil University, India), Wijerathne Bohingamuwa (Archaeology Department, University of Ruhuna, Sri Lanka)

5. Stone Age Seas: Mapping Voyages and Maritime Diffusions

Alice Kehoe (Marquette University, United States), Bettina Schulz Paulsson (University of Goteborg, Sweden)

6. Islamic Archaeology and the History of Maritime Southeast Asia and Beyond

Alexander Wain (International Institute of Advanced Islamic Studies (IAIS) Malaysia, Malaysia), Abhirada Komoot (University of Western Australia, Australia)

7. Maritime Archaeology in Latin America and Iberoamérica: New perspectives in the 21 st century

Nicolás Lira (Universidad de Chile, Chile), Alexandra Biar (Université Paris1/ArchAm UMR 8096, France), Nicolas Ciarlo (CONICET/Universidad de Buenos Aires, Argentina), Christophe Delaere (Oxford University/ ULB, Belgium) 


\section{F. Identities and Ontologies}

\section{Archaeologies of Identity}

1. Social and symbolic significance of Neolithic houses

Jan Turek (Center for Theoretical Study, Charles University, Prague, Czech Republic), Penny Bickle (University of York, United Kingdom), Daniela Hofmann (University of Bergen, Norway)

2. The Beaker Age. Exploring the Third Millennium BC spread of shared cultural identity in Eurasia

Jan Turek (Center for Theoretical Study, Charles University, Prague, Czech Republic), Kristian Kristiansen (University of Gothenburg, Sweden), Martin Furholt (Oslo University, Norway)

3. Archaeology in conflict zones: a zero-sum game?

Ghattas Jeries Sayej (Agder County Council, Kristiansand, Norway), Chemi Shiff (Faculty of Law, Haifa University., Israel), Akram Ijla (Independent researcher, Gotland., Sweden)

4. Children, Personhood and the Archaeology of Identity

April Nowell (University of Victoria, Canada), Jane Baxter (DePaul University, United States)

5. The Prehistory of Beer

Patrick E. Mc Govern (University of Pennsylvania Museum, United States), Jan Turek (Center for Theoretical Study, Charles University, Prague, Czech Republic), Elisa Guerra Doce (Facultad de Filosofía y Letras, Universidad de Valladolid, Spain)

6. Archaeology and Linguistics on the History of the Early Slavs

Florin Curta (University of Florida, Department of History, United States), Tomáš Klír (Charles University, Department of Archaeology, Czech Republic)

7. Entangled Africa: Identity and Inner-African Interaction

Steven Matthews (Deutsches Archäologisches Institut, Germany), Abigail Moffett (Department of Archaeology, University of Cape Town, South Africa), Thomas John Biginagwa (Department of Archaeology and Heritage, University of Dar es Salaam, Tanzania)

8. Prehistoric kinship beyond 'family': concepts, scales, inference, and significance

Stella Souvatzi (Hellenic Open University, Greece), Bradley E. Ensor (Eastern Michigan University, United States)

9. Landscape, Subsistence and Gender: The Eurasian Steppe in the Bronze Age

Natalia Berseneva (Institute of History and Archaeology, Ural Branch of Russian Academy of Sciences, Russian Federation), Emma Usmanova 
(Saryarka Archaeological Institute, Buketov Karaganda State University, Kazakhstan)

10. Discourse on Discursives: Outsiders, Outliers and Outlaws-archaeologies of fluid identities and queer mobilities

Catherine Frieman (Australian National University, Australia), Matthew Walsh (University of Oslo, Norway), Samantha Reiter (National Museum of Denmark, Denmark)

11. Crafting identities through ceramic practice. Global histories on the origins of pottery technology among foragers

Giulia D'Ercole (Ludwig-Maximilians-Universität (LMU) München, Germany), Elena A. A. Garcea (University of Cassino and Southern Latium, Italy), Lenka Varadzinová Suková (Charles University, Prague, Czech Republic), Ladislav Varadzin (Academy of Sciences of the Czech Republic, Prague, Czech Republic)

12. Vernacular \& Indigenous Material Culture and Architecture-Tracing the Homogeneity and Diversity

Durga Basu (Calcutta University, India), Sergiu Musteata (Ion Creanga State University, Moldova)

13. Approaching the sounds of the past. Music, acoustics and identity

Margarita Diaz-Andreu (ICREA, Universitat de Barcelona, Spain), Luboš Chroustovský (University of West Bohemia in Pilsen, Czech Republic)

14. Excavating Identity in Palestine from Prehistory to the Present

Nils Anfinsent (University of Bergen, Norway), Brian Boyd (Columbia University, United States), Hamed Salem (Birzeit University, Palestina)

15. Identity Dialogues: The Co-Construction of Archaeologies and Identities in the Arctic

Deirdre Elliott (Memorial University of Newfoundland, Canada), Kirstine Møller (Ilisimatusarfik-University of Greenland, Greenland)

16. Archaeology of meat-Meat as source of nutrition, status and identity

Günther Karl Kunst (VIAS-Vienna Institute for Archaeological Science University of Vienna, Austria), Krish Seetah (Department of Anthropology, Stanford University, United States), Jan Turek (Center for Theoretical Study, Charles University, Prague, Czech Republic)

17. Megaliths \& Earthworks: making the World together

Gail Higginbottom (Instituto de Ciencias del Patrimonio (Incipit), Consejo Superior de Investigaciones Científicas (CSIC), Spain), Cecilia Dal Zovo (Instituto de Ciencias del Patrimonio (Incipit), Consejo Superior de Investigaciones Científicas (CSIC), Spain), Felipe Criado-Boado (Instituto 
de Ciencias del Patrimonio (Incipit), Consejo Superior de Investigaciones Científicas (CSIC), Spain)

16. Landscapes, Forests, Groves, Rocks, Rivers, and Trees: Ontological Groundings and Seeking Alternative Theories

1. Archaeology, Language and Landscape

Tomáš Klír (Charles University, Faculty of Arts, Department of Archaeology, Czech Republic), Christian Zschieschang (Leibniz Institute for the History and Culture of Eastern Europe/GWZO/, Department "Man and Environment", Germany)

2. World Approaches to Landscape

James Scott Lyons (University of California, Berkeley, United States), Oki Nakamura (Ritsumeikan University, Japan), Andrea Creel (Independent Scholar, United States)

3. Community archaeology: Decolonizing archaeological practices to empower descendant communities

Valence Silayo (Stella Maris Mtwara University College, Tanzania), Tanambelo Rasolondrainy (Pennsylvania State University, United States), Nancy Rushohora (Stellenbosch University, South Africa)

4. Heritage and African Technological Ontologies: A dedication to Peter R. Schmidt

Kathryn Weedman Arthur (University of South Florida, United States), Innocent Pikirayi (University of Pretoria, South Africa), Chapurukha M. Kusimba (American University, United States)

5. Journey to the Historical Ruins of Ancient Cities

Adnan Uzun (Isik University, Faculty of Fine Arts, Turkey), Kellie Pollard (Flinders University, Australia)

G. Archaeologies and Sciences

17. The aDNA Revolution: Its Issues, Potentials, and Implications

1. Bones and Base Pairs: Progressing toward the integrated science of archaeogenetics (Round Table)

Kendra Sirak (Harvard Medical School, United States), Jakob Sedig (Harvard Medical School, United States), Elizabeth Sawchuk (University of Alberta, Canada)

2. Northeast Asia and the ancient DNA revolution in interdisciplinary perspective 
Martine Robbeets (Eurasia3angle, Max Planck Institute for the Science of Human History, Belgium), Chao Ning (School of Life Sciences, Research Center for Chinese Frontier Archaeology, Jilin University, China), Mark Hudson (Eurasia3angle, Max Planck Institute for the Science of Human History, Germany)

3. The Neolithization of East Asia inferred from a multidisciplinary perspective

Chuan-Chao Wang (Xiamen University, China), Ivy Hui-Yuan Yeh (Nanyang Technological University, Singapore), Lan-Hai Wei (Xiamen University, China), Rong Hu (Xiamen University, China)

\section{A New Bioarchaeology: Telling the Difficult Stories}

1. Beyond being a pastoralist in Central Asia: subsistence identities in light of bioarchaeological approaches sensu lato on human diet and mobility

Taylor Hermes (Kiel University, Germany), Elina Ananyevskaya (Vilnius University, Lithuania), Giedre Motuzaite Matuzeviciute (Vilnius University, Lithuania)

\section{Bioarchaeology in East Asia}

Hisashi Fujita (Niigata College of Nursing, Japan), Dong Hoon Shin (Seoul National University, Korea)

\section{Scientific Advances in East Asian Bioarchaeology}

Melanie Miller (University of Otago, New Zealand), Yu Dong (Shandong University, China)

4. Ethics in Bioarchaeology

Sian Halcrow (University of Otago, New Zealand), Kirsty Squires (Staffordshire University, United Kingdom), Pamela Geller (University of Miami, United States)

5. Reconstructing Past Human Behaviors and Identities through Advanced Zooarchaeological Methodologies and Technologies

Kara Larson (Mississippi State University, United States), Katharine Steinke (University of Edinburgh, United Kingdom)

6. What we can gain from analysis of masticatory system

Hiroko Hashimoto (Kyoto University, Japan), Carolyn Rando (University College London, United Kingdom), Ayako Shibutani (The University Museum, the University of Tokyo, Japan)

7. Colonial Legacies: Uncovering Colonial Stories and Dealing with Colonial Attitudes in Modern Bioarchaeology

Charlotte King (University of Otago, New Zealand), John Krigbaum (University of Florida, United States) 


\section{H. Environments}

19. Climates of Change and Environmental Pasts

1. Migration, Trade and Settlement patterns within extreme landscapes and challenging climatic conditions

Ekta Singh (HNB Garhwal University, India), Nagendra Singh Rawat (HNB Garhwal University, India), Stella Bickelmann (Museum of London Archaeology, United Kingdom)

2. Bridge and Barrier: the environmental and cultural history of Sahul and Wallacea

Richard (Bert) Roberts (University of Wollongong, Australia), Helen Farr (University of Southampton, United Kingdom)

3. Beyond Disturbed: Ecological Creativity though Fire

Matthew Walls (University of Calgary, Department of Anthropology and Archaeology, Canada), Petr Pokorný (Center for Theoretical study, Charles University and Czech Academy of Sciences, Czech Republic), Přremysl Bobek (Institute of Botany, Czech Academy of Sciences, Czech Republic)

4. Fields, peoples and power: approaches to agrarian archaeologies of the preindustrial world

Jesús Fernández Fernández (University of Oviedo, Spain), Alejandra Korstanje (University of Tucumán, Argentina), Gabriel Moshenska (UCL Institute of Archaeology, United Kingdom)

5. Islands of Sustainability?: Reexamining Issues of Human Impact to Insular Environments

Scott Fitzpatrick (University of Oregon, United States), Hiroto Takamiya (Kagoshima University, Japan)

6. Climate Change and Heritage

Sara Ayers-Rigby (Florida Public Archaeology Network; Florida Atlantic University Anthropology Department, United States), Elinor Graham (University of St Andrews, Scotland, United Kingdom), Vibeke Vandrup Martens (NIKU-Norwegian Institute for Cultural Heritage Research, Norway)

7. Interdisciplinary Studies of Human-Environment Interactions in Prehistoric North America

John Blong (Utah State University Museum of Anthropology, United States), Helen Whelton (University of Bristol, United Kingdom)

8. Within the Eye of the Storm: Gender, Age, Disability, Race, and Climate Change Through Time

Kimberly Kasper (Rhodes College, United States), Roderick Salisbury (Institute for Oriental and European Archaeology, Austrian Academy of Sciences and University of Vienna, Austria), Suzanne Spencer-Wood (Oakland University, United States) 
9. Evidence in Transition: Geoarchaeological Research into Periods of Significant Environmental Change

Jon-Paul McCool (Valparaiso, United States), Ladislav Varadzin (Institute of Archaeology of the Czech Academy of Sciences, Czech Republic), Lenka Varadzinova (Czech Institute of Egyptology, Faculty of Arts, Charles University, Czech Republic)

\section{Water and Ancient Complex Societies}

1. Securing Water in Freshwater Security and Urbanizing Landscapes in the Ancient Tropics

Innocent Pikirayi (University of Pretoria, South Africa), Federica Sulas (Aarhus University, Denmark)

2. Exploring urban-water dynamics in a comparative perspective: landscapes, management and uses until the Industrial Era

Laëtitia Deudon (University of Montreal and Polytechnic University of Hauts-de-France - Calhiste, EA 4343, Canada), Marion Foucher (ARTEHIS, UMR 6298, University of Bourgogne Franche-Comté, France), Camille Gorin (ArScAn, UMR 7041, Paris 1 Panthéon-Sorbonne University, France)

3. Medieval Inland Towns and Water

Rudolf Procházka (Archeologický ústav AVČR Brno, v.v.i, Czech Republic), Jerzy Piekalski (Instytut Archeologii Uniwersytetu Wrocławskiego, Poland)

4. The Long Term Impacts of Hydraulic Engineering in Tropical Low-Density Urban Societies

Keir Strickland (La Trobe University, Australia), Damian Evans (Ecole Française d'Extrême-Orient, France), Sarah Klassen (University of British Columbia, Canada), Patrick Roberts (Max Planck Institute for the Science of Human History, Germany)

\section{Reviving Water Infrastructures}

Adam Green (University of Cambridge, United Kingdom), Rekha Bhangaonkar (University of Cambridge, United Kingdom), Aftab Alam (Banaras Hindu University, India), Cameron Petrie (University of Cambridge, United Kingdom)

6. Water \& periphery: roads of water and roads in water

Vera Klontza-Jaklova (Department of Archaeology and Museology, Faculty of Arts, Masaryk University, Czech Republic), Miroslava Daňová (Department of Classical Archaeology, Faculty of Philosophy, Trnava University and Arts, Slovakia)

7. Sacred Power and Conspicuous Occupation: Riverine Islands in Global Perspective 
Patrick Morgan Ritchie (University of British Columbia, Canada), István Viczián (Geographical Institute, Hungarian academy of Science, Budapest, Hungary), Bill Angelbeck (Douglas College, Canada)

Z. World Archaeologies: The Past, the Present and the Future

21. World Archaeologies: the past, the present and the future

1. Biological or Behavioral: Multidisciplinary perspectives on Mode 2 to Mode 3 transitions across the Old World

Anil kumar devara (Department of Archaeology and Ancient History, the MS University of Baroda, India), Javier Baena (Prehistoria y Arqueología. Universidad Autónoma de Madrid, Spain), Parth Chauhan (Dept. of Humanities \& Social Sciences Indian Institute of Science Education \& Research, Mohali, Punjab, India)

2. Roundtable on Community-Driven Reproducible Research: The Community for Modeling Agropastoralism in Eurasia (C-MAPLE) (Round Table)

Isaac Ullah (San Diego State University, United States), Francesco Carrer (Newcastle University, United Kingdom)

3. River cultures: Collapse and growth

Ioannis Liritzis (University of The Aegean, Greece EL), Changong Miao (Henan University, China)

4. World archaeo-geophysics: State of the art \& case studies (COST Action SAGA-CA 17131)

Carmen Cuenca-Garcia (Norwegian University of Science and Technology (NTNU), Norway), Andrei Asandulesei ("Al.I. Cuza" University, Romania), Kelsey Lowe (University of Queensland, Australia)

5. Bridging the animal-human technological interface: Understanding the patterns and factors influencing tool-use in human and non-human populations

Jayashree Mazumder (Indian Institute of Science Education and Research, Mohali (IISER, Mohali), India), Andrea Bamberg Migliano (University of Zurich, Switzerland)

6. Remote sensing in the documentation, monitoring and research of archaeological landscapes

Martin Gojda (University of West Bohemia, Czech Republic), Stephen Davis (University College Dublin, Ireland)

7. Developers and Archaeology: Global Perspectives

Caleb Adebayo Folorunso (University of Ibadan, Nigeria), Charles Le Quesne (Environmental Resources Management (ERM), United Kingdom) 
8. "Being human": Integrated approach to the transformation of the material world, through cognitive experiences of body and mind

Naoko Matsumoto (Okayama University, Japan), Liliana Janik (University of Cambridge, United Kingdom)

9. Archaeology from the Next Generation: Student-Led Research Projects in a Global Perspective

Erin Hogg (Simon Fraser University, Canada), José Ant. Mármol Martínez (Complutense University Madrid, Spain), Yajaira Núñez Cortés (University at Albany-SUNY, Costa Rica)

10. Battle fields and armed conflicts of the $15^{\text {th }}-19$ th Century in historical memory and reality

Ladislav Rytír (University of Hradec Králové, Czech Republic), Martin Neumann (Comenius University in Bratislava, Slovakia), Grzegorz Podruczny (Adam Mickiewicz University Poznan, Poland)

11. Student Ethics Debate, Hosted by the WAC Student Committee (Round Table)

Gonzalo Linares (St. Hugh's College (University of Oxford), United Kingdom), Hannah Quaintance (University at Buffalo, State University of New York (SUNY), United States), Marian Bailey (Flinders University, Australia)

12. Mobility, migrations and diasporas from the perspective of world archeologies

Mariano Bonomo (CONICET-Universidad Nacional de La Plata, Argentina), Mónica Berón (CONICET-Universidad de Buenos Aires, Argentina), José López Mazz (Universidad de la República, Uruguay), Fernado Ozorio de Almeida (Universidade Federal de Sergipe, Brazil)

13. Global Archaeological Ethics: 2020 and beyond

Dru McGill (North Carolina State University, United States), Alexander Herrera Wassilowsky (Universidad de los Andes, Colombia), Margaret Rika-Heke (Heritage New Zealand Pouhere Taonga, New Zealand)

14. Environmental Archaeology of Ancient Complex Societies in East Asia

June-Jeong Lee (Seoul National University, Korea), Sei-ichiro Tsuji (The University of Tokyo, Japan), Xuexiang Chen (Shandong University, China)

15. The collapse of ancient societies

Junko Uchida (Institute of History and Philology, Academia Sinica, Japan), Kuei-chen Lin (Institute of History and Philology, Academia Sinica, Taiwan)

16. South Asia and the World: Tackling the big archaeological questions through South Asian evidences

Akash Srinivas (Indian Institute of Science Education and Research (IISER) Mohali, India), Nupur Tiwari (Indian Institute of Science Educa- 
tion and Research (IISER) Mohali, India), Francesc Conesa (McDonald Institute for Archaeological Research, University of Cambridge, United Kingdom), Adam Green (McDonald Institute for Archaeological Research, University of Cambridge, United Kingdom), Yezad Pardiwalla (Indian Institute of Science Education and Research (IISER) Mohali, India)

17. The Arts of Sacred Healing: World Archaeologies, Global Interconnections

Wendelin Morrison (Bournemouth University, United Kingdom), Timothy Darvill (Bournemouth University, United Kingdom), Oki Nakamura (Ritsumeikan University, Japan)

18. Memory (and forgetting) in archaeology

Carola Metzner-Nebelsick (Ludwig-Maximilians-Universität München, Archeology Department, Germany), Timothy Taylor (University of Vienna, Austria)

19. Challenges and new approaches for protection of cultural heritage around the world

Marika Tisucká (National Museum of Prague, Czech Republic), Isber Sabrine (Researcher and Cultural Heritage Manager | Institució Milà i Fontanals CSIC and Heritage for Peace, Spain), Emma Cunliffe (The Blue Shield/Newcastle University, United Kingdom)

Publisher's Note Springer Nature remains neutral with regard to jurisdictional claims in published maps and institutional affiliations. 